\title{
When the Rabbi's Soul Entered a Pig: Melchiorre Palontrotti and His Giudiata against the Jews of Rome
}

\author{
MARTINA MAMPIERI \\ Lichtenberg-Kolleg, Georg-August-Universität Göttingen, Göttingen, Germany \\ E-mail: martina.mampieri@gmail.com
}

\begin{abstract}
This essay analyzes an unpublished manuscript of a giudiata, a poem mocking Jewish funerals that was written and performed in Rome in the mid-seventeenth century. Melchiorre Palontrotti, the author of the composition, was a Roman polemist and author of other published works against Italian Jews, including, among others, the Venetian rabbi Simone Luzzatto, between 1640 and 1649. After furnishing information on the author and the historical background in which the song was written, and following an analysis of the origins of giudiate and their diffusion in early modern Rome, this paper explores the content, language, and style of the giudiata text. The appendix includes a bibliography of Palontrotti's writings and a transcription of the manuscript.
\end{abstract}

Keywords Jewish-Christian Relations · Jewish History · Anti-Jewish Polemics · Early Modern Polemics $\cdot$ Seventeenth Century $\cdot$ Rome

In the rich manuscript collection belonging to Giovanni Pastrizio (ca. 16361708), ${ }^{1}$ a lecturer in theology at the Collegio Urbano de Propaganda Fide and scriptor hebraicus at the Vatican Library from 1695, there is a brief but extremely interesting rhymed composition. ${ }^{2}$ This text, handwritten by Pastrizio, consists of a canzone contro gli ebrei ("song against the Jews") in

\footnotetext{
${ }^{1}$ On Pastrizio, also known as Ivan Paštrič, and his activity in Rome from the first half of the seventeenth century until his death, see Notizie istoriche degli Arcadi morti, tomo secondo, in Roma, nella Stamperia di Antonio de Rossi, 1720, f. 148; Tomislav Mrkonjić OFM, Il Teologo Ivan Paštrič (Giovanni Pastrizio) (1636-1708). Vita, opere, concezione della teologia, cristologia (Rome, 1989); idem, "Pastrizio, Giovanni," Dizionario Biografico degli Italiani 81 (2014): 703-5; Marina Caffiero, Battesimi forzati. Storie di ebrei, cristiani e convertiti nella Roma dei papi (Rome, 2004), 40; 67-68; Bruno Gialluca, "Gli Antichi Sepolcri e Ivan Pastric (Giovanni Pastrizio). Ricerche sopra la produzione estrema di Pietro Santi Bartoli," Symbolae Antiquariae 5 (2012): 23-106. On Pastrizio's involvement in the censorship of a Hebrew work, Seder 'Olam, see Paola Vismara, "Van Helmont, Franciscus Mercurius," Dizionario storico dell'Inquisizione, III, ed. Adriano Prosperi in collaboration with Vincenzo Lavenia and John Tedeschi (Pisa, 2010), 1652. The giudiata by Palontrotti is in a volume of miscellaneous manuscripts written by Pastrizio and housed in the Fondo Borgiano Latino (abbreviated as Borg. Lat.) at the Vatican Apostolic Library (from now onwards, BAV). Unless otherwise indicated, all translations from Italian and Hebrew into English are my own.

${ }^{2}$ BAV, Borg. Lat. 481, Canzone contro gli ebrei. Precedono notizie su Melchiorre Pallantrotti di mano di Giovanni Pastrizio, ff. 172r-174r.
} 
Judeo-Roman (giudaico-romanesco or giudeo-romanesco), the dialect spoken by the Jews of Rome as early as the fifteenth century and whose features are present in earlier literary Judeo-Italian texts. ${ }^{3}$ The song was apparently performed in the Roman ghetto in the mid-seventeenth century, but how and when it reached Pastrizio's hands is not known. ${ }^{4}$ Before his transcription of the text, he provided some information about its author and context, adding that it "was believed to be the first giudiata ever performed in Rome." ${ }^{5}$ But what was a giudiata? In his Comentarj intorno all'istoria della volgar poesia (Rome, 1702), Giovan Mario Crescimbeni defined giudiate as popular farces that were usually performed in the Roman rioni (the regions into which Rome was divided) during the Carnival. They owed their name to their mocking imitation of the Jews, who were represented in odd and discourteous ways. ${ }^{6}$

\footnotetext{
${ }^{3}$ Many important works have been devoted to the study of giudeo-italiano and the dialects spoken by Italian Jews in different geographical areas such as giudaico-romanesco in Rome, bagitto in Livorno, and local Jewish dialects in Ferrara, Mantua, Venice, and other places. For a detailed examination of the phonetical, morphological, and syntactical features of the language spoken and written by Roman Jews in the fifteenth and sixteenth centuries, see Sandra Debenedetti Stow, "Testimonianze dal vivo: la lingua degli ebrei romani negli atti dei notai ebrei, fra Cinque e Seicento," La Rassegna Mensile di Israel 67/1-2 (2001): 373-410. On the language spoken by Italian Jews, see Umberto Fortis, La parlata degli ebrei di Venezia e le parlate giudeo-italiane (Florence, 2006); Maria Mayer Modena, "Le parlate giudeo-italiane," in Storia d'Italia. Annali, Gli ebrei in Italia 11, ed. Corrado Vivanti, II, Dall'emancipazione a oggi (Turin, 1997): 939-63; and Aaron D. Rubin, "Judeo-Italian," in Handbook of Jewish Languages, ed. Aaron D. Rubin and Lily Khan (Leiden, 2016), 297-364, 324-25.

${ }^{4}$ Pastrizio was very active in purchasing Hebrew books and manuscripts for the Vatican Library and for his own. At his death, his personal collection was incorporated into that of Cardinal Stefano Borgia (1731-1804) in the library of the Museo Borgiano di Propaganda Fide, which was acquired by the Vatican Library in 1902. See Benjamin Richler (ed.), Hebrew Manuscripts in the Vatican Library. Catalogue Compiled by the Staff of the Institute of Microfilmed Hebrew Manuscripts in the Jewish National and University Library, Jerusalem, Paleographical and Codicological Descriptions by Malachi Beit-Arié in collaboration with Nurit Pasternak (Città del Vaticano, 2008), xvii-xviii; Cesare Pasini, "Il catalogo dei manoscritti ebraici della Vaticana: una fruttuosa collaborazione con la Biblioteca Nazionale di Gerusalemme," L'Osservatore Romano, October 30, 2008. On the Borgia collection stored in the Vatican Library, see Paola Orsatti, Il fondo Borgia della Biblioteca Vaticana e gli studi orientali a Roma tra Sette e Ottocento (Città del Vaticano, 1996) and the bibliography cited in Benjamin Richler (ed.), Guide to Hebrew Manuscript Collections, second revised edition (Jerusalem, 2014), 38.

${ }^{5}$ BAV, Borg. Lat. 481, f. $172 r$.

${ }^{6}$ Giovan Mario Crescimbeni, Comentarj del canonico Gio. Mario Crescimbeni custode d'Arcadia intorno alla sua istoria della volgar poesia (Rome, 1702), 198: "Ma molto più delle Zingaresche s'assomigliano alle farse quelle popolari rappresentazioni, che soglion fare nel carnovale i rioni di Roma sopra i carri tirati da buoi, le quali si chiamano Giudiate, perciocché in esse non si tratta d'altro, che di contraffare, e schernire gli Ebrei in istranissime guise, ora impiccandone per la gola, ora strangolandone, ed ora scempiandone, e facendone ogn'altro più miserabil giuoco."
} 
According to the poet's description, these farces were written in verse "in different corrupted and distorted languages, all mixed together" and were "sung in a singsong fashion by many silly characters."7 Both Jews and Christians considered this combination of languages and idioms to be the genuinely distinctive feature of the giudiate. In his Via della fede mostrata agl'ebrei (Rome, 1683), the famous convert Giulio Morosini (born Samuel ben David Nahmias, 1612-1683) wrote that the Jews had a poor knowledge of Hebrew and that they spoke it very badly, as they did in the giudiate through which the Christians mocked them. ${ }^{8}$

The giudiate were staged on carts (carri) pulled by oxen and decorated with laurel branches or other plants and, according to Crescimbeni, they "were sung [...] and accompanied by sounds [...] and whenever they were performed — both at daytime and at night — a vast multitude would draw near and listen with great enjoyment and laughter." ${ }^{\prime 9}$ Indeed, since these plays were itinerant, they could have been seen by numerous bystanders in many parts of the city on the same day. Paolo Toschi added that the giudiate often concluded with dances. ${ }^{10}$ Aside from this information, very little is known about their composition and performance history, and even less about the identity of the authors who composed these farcical plays and the actors who took part in them.

The present article aims to shed light on this still little-known subject by considering the case of an unpublished giudiata composed by a Roman polemicist, Melchiorre Palontrotti. After introducing the author and his published writings, this study addresses the origins of the giudiate in relation to the Roman Carnival. It then moves on to illustrate and analyze the distinctive features of Palontrotti's giudiata - its content, style, and language- the full text of which is provided in the appendix. Lastly, I offer some final reflections on typical representations of Jews - the ways in which they spoke, acted, and interacted-and how they evolved in early modern theater into actual antisemitic stereotypes.

\section{Melchiorre Palontrotti and His Literary Production}

According to Pastrizio's preamble, the author of the giudiata was a certain Melchiorre (or Melchior) Pallontrotti (or Palontrotti, sometimes also Pallantrotti), "a Roman citizen who was very well versed in Hebrew and a fierce

\footnotetext{
${ }^{7}$ Ibid.

${ }^{8}$ See Giulio Morosini, Derekh emunah. Via della fede mostrata agl'ebrei, second part (Rome, 1683), 1187: "Parlo della lingua, che da gli Ebrei è talmente ignorata, che non la parlano, se non nel modo che li burlano i Christiani con le Giudiate."

${ }^{9}$ Crescimbeni, Comentarj, 198.

${ }^{10}$ See Paolo Toschi, Le origini del teatro italiano (Turin, 1955), 335.
} 
enemy of the Jews of Rome."11 The details of his biography are scant. Although there is no certain proof, it may be that he was a descendant of another Melchiorre (or Melchior) Palontrotti (Venafro, ca. 1570-1614), a celebrated virtuoso bass singer who, according to Michelangelo Buonarroti the Younger (1568-1646), was "an excellent musician of Our Lord's Chapel.".12

In his concise introduction, Pastrizio noted that our Palontrotti published his works in order "to counter their [the Jews'] nonsense" and that he was a regular visitor to synagogues, where "he would mock the Jews and often attended their sermons, interrupting the rabbi and making him notice their nonsense." 13 While it may be true that in the early modern period, "Christian travelers who came to synagogues or Jewish houses in order to observe how Jews celebrate their holidays or perform circumcisions or marriages, normally were not interested in polemics," 14 polemicists were not in the least motivated by ethnographical aims. As testified throughout the history of Jewish-Christian encounters, synagogues were at times theaters of theological controversy and even physical altercations. ${ }^{15}$ "Simultaneously and selec-

$\overline{{ }^{11} \text { BAV, Borg. Lat. 481, f. } 172 r}$.

${ }^{12}$ Opere varie in versi ed in prosa di Michelangelo Buonarroti il Giovane alcune delle quali non mai stampate raccolte da Pietro Fanfani (Florence, 1863), 431. It seems that this singer had left his position at the Sistine Chapel in 1603, perhaps to sing in the court of the Viceroy of Naples. Five years later, Paul V ordered the cardinal-protector of the cappella, Antonio Maria Gallo, to summon all the singers in order to discuss Palontrotti's readmission, even though he was married. Choir members rejected the pope's request, "simply [... ] pointing out that Palontrotti was in poor health and that this would certainly affect the regularity of his attendance." See Jean Lionnet, "The Borghese Family and Music During the First Half of the Seventeenth Century," trans. Norma Deane and John Whenham, Music and Letters 74/4 (1993): 519-29, 520, and Richard Wistreich, "Palontrotti, Melchiorre," Dizionario Biografico degli Italiani 80 (2014). On the hypothesis regarding the origins of the family name, see Claudio Annibaldi, $L a$ Cappella Musicale Pontificia nel Seicento, vol. 1, Da Urbano VII a Urbano VIII, 1590-1644 (Palestrina, 2011), 94 n. 47.

${ }^{13}$ BAV, Borg. Lat. 481, f. $172 r$.

${ }^{14}$ Günter Stemberger, "Introduction," in Ritual Dynamics in Jewish and Christian Contexts. Between Bible and Liturgy, eds. Claudia D. Bergmann and Benedikt Kranemann (LeidenBoston, 2019), 5. In sixteenth-century Amsterdam, citizens and travelers would visit the synagogues of the three Sephardi congregations. See Yosef Kaplan, An Alternative Path to Modernity: The Sephardi Diaspora in Western Europe (Leiden-Boston-Köln, 2000), chapter 2. On ethnographic writing, see Yaacov Deutsch, Judaism in Christian Eyes. Ethnographic Descriptions of Jews and Judaism in Early Modern Europe (Oxford, 2012).

${ }^{15}$ For example, in his 'Emeq ha-Bakha, Yosef ha-Cohen narrates that on Yom Kippur 5319 (1558), the neophyte Filippo Herrera (born Salomon Romano, not Yosef Morro as erroneously indicated in Martina Mampieri, Living under the Evil Pope: The Hebrew Chronicle of Pope Paul IV by Benjamin Nehemiah ben Elnathan from Civitanova Marche (Leiden-Boston, 2020), 95.) broke into the Recanati synagogue and placed a crucifix in the aron where the Torah scrolls were stored. When Jews attempted to drive him away, Christians came to help him and 
tively both porous and protective,"16 the walls of the ghetto did not prevent Christians from having contact with Jews, and despite frequent papal decrees, they continued meeting in taverns, drinking, gambling, and eating together. ${ }^{17}$ It is therefore not difficult to imagine polemicists such as Palontrotti taking advantage of these blurred boundaries to engage Jews in polemics and to mock their rites.

Details of Palontrotti's education-particularly his proficiency in Hebrew -are obscure. It is not known whether he studied Hebrew alone or was tutored by a Jewish teacher in Rome. Nor is there evidence that he was a convert or a priest. ${ }^{18}$ What is certain is that sources other than Pastrizio refer to the great appreciation by Palontrotti's contemporaries for his mastery of the Hebrew language. The erudite Roman polemicist Francesco Maria Torrigio (1580-1649), for instance, reported that Palontrotti was asked to decipher a fragmentary marble inscription found behind the Church of San Benedetto and Lorenzo in Trastevere that would have proven that this was the location of the old synagogue when the Jews lived in that area in 44 CE, when St. Peter arrived in Rome. 19 "The inscription," according to Torrigio, "was written in Hebrew characters, partly abbreviated, and particularly hard [to decipher]." 20

surrounded the synagogue; two Jews were arrested and publicly flogged. See Yosef ha-Cohen, El Valle del Llanto ('Emeq ha-Bakha), ed. Pilar León Tello (Madrid-Barcelona, 1989), 156. Quarrels between Jews and Christians were frequent in Jewish neighborhoods and even within the synagogue walls. See Daniel Jütte, “'They Shall Not Keep Their Doors or Windows Open': Urban Space and the Dynamics of Conflict and Contact in Premodern Jewish-Christian Relations," European History Quarterly 46/2 (2016): 209-37; and Ariel Toaff, "La vita materiale," Storia d'Italia. Annali, Gli ebrei in Italia 11, ed. Corrado Vivanti, I, Dal Medioevo all'età dei ghetti (Turin, 1996): 250.

${ }^{16}$ Kenneth R. Stow, Theater of Acculturation. The Roman Ghetto in the Sixteenth Century (Seattle-London, 2001), 91.

${ }^{17}$ Ibid., 45. Scholars have long noted that meetings between Jews and Christians took place at night, when the walls of the ghetto were closed. For a recent interpretation of the phenomenon, see Dana E. Katz, The Jewish Ghetto and the Visual Imagination of Early Modern Venice (Cambridge, 2017), 84-111.

${ }^{18}$ This last suggestion was formulated by Salo W. Baron in his book review of Dante Lattes's edition and English translation of Luzzatto's Discorso; see Salo W. Baron, "Ma'amar 'al Yehudei Venetzia (Discourse on the Status of the Jews in Venice) by Simha (Simone) Luzzatto and Dante Lattes," Jewish Social Studies 15/3-4 (1953): 313-14.

${ }^{19}$ Francesco Maria Torrigio, I sacri trofei romani del trionfante prencipe degli apostoli San Pietro gloriosissimo (Rome, 1644), 110.

${ }^{20}$ Ibid., 111. Torrigio transcribed the Hebrew inscription, followed by Palontrotti's interpretation, transliteration, and Latin translation: "Le parole di essa sono queste interpretate dall'Ebreo dal Sig. Melchiorre Palontrotti eruditissimo della lingua santa.

קדש ל"ה ביב"ב ק"ק רנם הארבעה ראשים: קדש לה' בירושלים במהרה ביומינו קהל קדוש רנם הארבעה ראשים. Kodesc ladonai biruscialaim bimharah beiomenu Kehal Kadosc rinnam haarbanghah rascim. Sanctitas Deo in Ierusalem cito in diebus nostris Congregatio Sancta Canticorum quatuor capitum" (Torrigio, I sacri trofei, 111-12). 
Palontrotti's proficiency in Hebrew language and literature is also confirmed by Carlo Giuseppe Imbonati (d. 1697) who, in his Bibliotheca LatinoHebraica, referred to him as vir in Sacra, et Hebraica literatura apprime versatus ("well versed in both biblical and Jewish literature"). ${ }^{21}$ It seems that this description was uttered for the first time by Giovanni Nicheo, a Dalmatian theologian and a lecturer in Hebrew who, among other things, had taught Giovanni Pastrizio along with Giulio Bartolocci in the Collegio dei Neofiti e Transmarini in Rome. ${ }^{22}$ As far as can be seen from the edition of Palontrotti's Disputa del Christiano con l'Ebreo (Rome, 1647), which was composed at the request of a certain Pietro Paolo Romaldi, Nicheo, who was invited to review the text by the Master of the Sacred Palace, approved it for publication on October 3,1647. Added to the text was a preface praising the author and the quality of the work, which was intended to encourage the conversion of the Jews. ${ }^{23}$ This was apparently not the only case in which Palontrotti authored texts with an evident conversionist aim. From the title page of another work, the Breve raccolta d'argomenti (Venice, 1649), we learn that the work was "necessary for preachers and catechists" and "extremely useful for helping the Jews to recognize their obvious stubborn incredulity," and that it was also intended to help Christians "in strengthening their faith in Our Lord Jesus Christ, true King of Israel, true Messiah, and Savior of the World." ${ }^{4}$ The

\footnotetext{
${ }^{21}$ Carlo Giuseppe Imbonati, Magen ve-Herev u-Milhamah. Bibliotheca Latino-Hebraica siue de scriptoribus Latinis, qui ex diuersis Nationibus contra Judaeos uel de re hebraica utcumque scripsere (Rome, 1694), 160-61. See also Julius Fürst, Bibliotheca judaica, III (Leipzig, 1863), 64; Johann C. Wolf, Bibliotheca Hebraea, I (Hamburg, 1715), 1146; II (Hamburg, 1721), 1039; Moritz Steinschneider, "Letteratura antigiudaica in lingua italiana," Il Vessillo Israelitico 30 (1882): 245.

${ }^{22} \mathrm{~A}$ list of the members of this Collegio (1585-1713) who hailed from the Balkans is in BAV, Vat. Lat. 14158. See Tomislav Mrkonjić, "Učenici iz hrvatskih krajeva u zavodu neofita i transmarina u Rimu od 1585. do 1713. (Cod. Vat. Lat. 14158)," Croatica Christiana Periodica 11/19 (1987): 26-30.

${ }^{23}$ Melchiorre Palontrotti, Disputa del Christiano con l'Ebreo di Melchior Palontrotti. Ad istanza di Pietro Paolo Romaldi. Dove si prova chiaramente contra l'ebreo, che la ridutione temporale, che aspetta fù adempita nella liberatione di Babilonia, in Roma, appresso Girolamo Barbèri, 1647: "D. Melchior Palontrottus Vir in Sacra et Hebraica literatura apprime versatus, scripsit Tractatum de Congregatione dispersionis Israel, cui Titulus (Disputa del Christiano con l'Ebreo) Reverendissimus Magister Sac. Ap. iussit Librum a me examinari. Et iudico illum publica luce, et laude dignissimum; cum sit pius, doctus, et Hebreorum conversionis satis accomodatus. Romae die tertia Octobris 1647. Ita censeo Ioannes Nicheus."

${ }^{24}$ Breve raccolta d'argomenti cavati dalla Sac. Scrit. \& dall'Antiche tradittioni di Rabbini, con le quali chiaramente si provano i dogmi della Religion Christiana contra l'Hebraica perfidia. Opus utilissimum Iudaeis ad eorum obstinationem, et incredulitatem agnoscendam, in Venetia, appresso Giovanni Giacomo Herz, 1649. On this work, see Giulio Busi, "La Breve raccolta (Venezia, 1649) del polemista antigiudaico Melchiorre Palontrotti," Annali di Ca' Foscari. Rivista della Facoltà di lingue e letterature straniere dell'Università di Venezia 24/3 (1985): 1-19.
} 
work is dedicated to the governors of the Congregation of the Catechumens of Venice, who administered the Holy House (Pia Casa dei Catecumeni) established there in $1557 . .^{25}$

Another of Melchiorre Palontrotti's works, Breve risposta to Rabbi Simone (Simha) Luzzatto (1583?-1663), is also connected to Venice. Printed in Rome in 1641, the text is a polemical response to Luzzatto's Discorso circa il stato de gl'Hebrei et in particolar dimoranti nell'inclita città di Venetia (Venice, 1638). ${ }^{26}$ In his short pamphlet, "Palontrotti used the Discorso as a point of departure for citing biblical verses with their standard accepted Christian anti-Jewish interpretations," though he did also "make a few valid criticisms of some of the weaker apologetical arguments advanced in the Discorso," such as the Jews' loyalty and their obedience to the law. ${ }^{27}$ Other works published by Palontrotti include seven lessons on the Psalms that were delivered on various occasions. ${ }^{28}$ The Lesson on Psalm 36, for instance, was taught at the academy of Monsignor Alessandro Sperelli (1589-1672), who was the bishop of Gubbio and a member of the Accademia degli Insensati in Perugia. $^{29}$

Palontrotti's giudiata not only aimed to provoke laughter at the Roman Jews' expense but also appears to have been perfectly aligned with his other polemical writings. However, in contrast to these works, the text of the giudiata never saw the light of day. According to the information provided by

\footnotetext{
${ }^{25}$ See E. Nathalie Rothman, "Becoming Venetian: Conversion and Transformation in the Seventeenth-Century Mediterranean," Mediterranean Historical Review 21/1 (2006): 39-75. For a case of religious dissimulation inside the House of the Catechumens in Venice, see Adelisa Malena, "A Hybrid Identity: Jewish Convert, Christian Mystic and Demoniac," in Dissimulation and Deceit in Early Modern Europe, ed. Miriam Eliav-Feldon and Tamar Herzig (New York, 2015), 110-29.

${ }^{26}$ Breve risposta a Simone Luzzatto ebreo, in Roma, appresso Manelfo Manelfi, 1641. On the Discorso, see now the new annotated edition and English translation by Giuseppe Veltri and Anna Lissa (eds.), Discourse on the State of the Jews. Bilingual edition (Berlin, 2019). On the dispute between Luzzatto and Palontrotti, see Benjamin Ravid, "Contra Judaeos in Seventeenth-Century Italy: Two Responses to the Discorso of Simone Luzzatto by Melchiore Palontrotti and Giulio Morosini," AJS Review 7-8 (1982-83): 301-51 (repr. in idem., Studies on the Jews of Venice, 1382-1797, Aldershot, 2003). For a biographical profile of this important rabbi, see the entry "Luzzatto, Simone" by Giuseppe Veltri and Michela Torbidoni in Encyclopedia of Renaissance Philosophy, ed. Marco Sgarbi (2016): 1-6, doi:10.1007/978-3-319-02848-4_147-1.

${ }^{27}$ The quotation is from Ravid, “Contra Judaeos in Seventeenth-Century Italy, 304.

${ }^{28}$ These occasions are evident from some of the title pages. For a complete bibliography of Palontrotti's works, see the list appended below. On his lessons on the Psalms, see Fausto Parente, "Il confronto ideologico tra l'Ebraismo e la Chiesa in Italia," in Italia Judaica. Atti del I Convegno internazionale. Bari, 18-22 maggio 1981 (Rome, 1983), 303-81, 335-38.

${ }^{29}$ See Salvatore Geruzzi (ed.), La lunga ombra dell'Accademia. Alessandro Sperelli, vescovo di Gubbio, 1644-1672 (Pisa, 2005).
} 
Pastrizio, the giudiata can be dated to either 1647 or 1648, or "just before or shortly after" those years. At that time, after the publication of his Lesson on Psalm 84 (Rome, 1642) and the Sferza contro l'ostinazione, et pervicacia de gl'ignoranti Ebrei (Bracciano, 1642), Palontrotti was working on the Disputa del Christiano con l'Ebreo (Rome, 1647) and the Breve raccolta (Venice, 1649).

\section{Carnival Violence against the Jews: A Long-Standing Roman Tradition}

As is known from the many excellent studies on Carnival games in the late medieval and early modern period, the Jewish community of Rome had a fundamental role in these celebrations. ${ }^{30}$ Often, episodes of anti-Jewish violence erupted. The Jews' participation followed precise rituals of humiliation and mockery during the Roman Carnival, and those who lived in the Papal States had to pay an annual tax of 1,130 florins for the games of Agone and Testaccio. ${ }^{31}$ According to Simonsohn, "when Paul II imbued the festivities with new life, the Jews again took part willingly at first, although the tax was retained. Eventually the Jewish participation again became a ludicrous and painful farce." 32 Roman Jews were forced to run naked down the Via Lata (hence "Via del Corso") to Testaccio in the so-called palio or corso degli he-

\footnotetext{
${ }^{30}$ These include Emanuel Rodocanachi, Le Carnaval à Rome au XVe et au XV siècle (Amiens, 1890); Filippo Clementi, Il Carnevale romano nelle cronache contemporanee con illustrazioni riprodotte da stampe e quadri dell'epoca (Rome, 1899); Elio Toaff, "Il Carnevale di Roma e gli ebrei," in Scritti in memoria di Sally Mayer (1875-1953): Saggi sull'ebraismo italiano, ed. Umberto Nahon (Jerusalem-Milan, 1956), 325-43; Martine Boiteux, "Les Juifs dans le Carnaval de la Rome moderne (XV $\mathrm{XV}^{\mathrm{e}} \mathrm{XVIII}{ }^{\mathrm{e}}$ siècles)," Mélanges de l'École française de Rome. Moyen-Age, Temps Modernes 88/2 (1976): 745-87; idem, "Cornomania e Carnevale a Roma nel Medioevo," La Ricerca Folklorica 6 (1982): 57-64; Beatrice Premoli, "Ludus carnelevarii". Il Carnevale a Roma dal secolo XII al secolo XVI (Rome, 1981); Maria Antonietta Visceglia, La città rituale. Roma e le sue cerimonie in età moderna (Rome, 2002); Marina Caffiero, "Il Carnevale degli ebrei a Roma in età moderna," in Carnevale romano. Rinascita di una tradizione (Rome, 2012), 127-39.

${ }^{31}$ These names came from the places where the games were held: Campus Agonis (then known as Piazza Navona) and Mons Testaccius. In the words of Shlomo Simonsohn, "these had their origin at an unknown date in the Middle Ages. According to Martin V, they were meant to celebrate the Christian victory in Jerusalem and the miraculous headcloth of St. Veronica." See Shlomo Simonsohn, "The Jews in the Papal States to the Ghetto," Italia Judaica. Gli ebrei nello Stato pontificio fino al Ghetto (1555). Atti del VI Convegno internazionale, Tel Aviv, 18-22 giugno 1995 (Rome, 1998), 19. On the annual tax, which was abolished in 1847, see Attilio Milano, Il ghetto di Roma: Illustrazioni storiche (Rome, 1964), 130-31; idem, Storia degli ebrei in Italia (Turin, 1992), 600; Kenneth R. Stow, Taxation, Community, and State: The Jews and the Fiscal Foundations of the Early Modern Papal State (Stuttgart, 1982), 3; 32; 169-70.

${ }^{32}$ Simonsohn, "The Jews in the Papal States to the Ghetto," 19.
} 
brei or judei ("Jews' race") every year until 1668, when it was abolished and replaced with another tax. ${ }^{33}$

According to a seventeenth-century Italian manuscript produced by an anonymous chronicler and preserved in the Vatican Library, one of the cruelest forms of entertainment performed during the early medieval Carnival was the tradition of forcing the community's oldest Jew into a barrel filled with nails and then pushing it down Monte Testaccio: ${ }^{34}$

Since it culminated in death, this medieval practice has been identified as a vestige of the ancient rites of exorcising evil during the spring festivals. It was accompanied by singing and dancing, which included the spectators thus involving them as a sort of chorus in the giudiata. The Jew here figured as a scapegoat, sacrificed as the Carnival "King." Perhaps, too, this commemorated the Passion, the suffering of Christ, "King of the Jews." 35

This last interpretation seems particularly symbolic, as eventually the Jewish community managed to avert this sacrifice by replacing the Jew with two

\footnotetext{
${ }^{33}$ Ibid. Clement IX put an end to the Jews' races during the Carnival with a papal chirograph dated January 28,1668 , but he obliged them to pay homage before the Conservatori-namely, the highest Roman civic officials-from the thirteenth century until 1870 . The Jews were required to pay 300 scudi every year in order to be exempted from the footraces. According to Elio Toaff, the sum amounted to 531 scudi per year; see Toaff, "Il Carnevale di Roma," 334. An excerpt from Clement IX's breve is published in Milano, Il ghetto di Roma, 319. As noted by David Freedberg, evidence of these footraces is found in many contemporary sources such as the Avvisi di Roma, which provide information on aspects of social and political life in Rome and several other issues, such as weather conditions that affected the Carnival (which typically occurred during February or early March). See David Freedberg, "Cassiano on the Jewish Races of Rome," Quaderni Puteani 3/2 (1992): 41-56, 53 n. 41. The amazing collection of Avvisi covering the years 1554 to 1648 is preserved in the Fondo Urbinate Latino of the Vatican Library. These sources were handwritten newsletters, gazettes written by ambassadors, messengers, or agents or bought by them from gazetteers to inform their princes and masters about social and political life in Rome in general and at the papal court in particular. Among other testimonies, Michel de Montaigne also witnessed the palio during his visit to Rome in 1580-1581, and in his Journal du Voyage, he noted that several groups of children, Jews, and naked elderly men took part in the footraces: "Le long du cours, qui est une longue rue de Rome, qui a son nom pur cela, on faict courir à l'envi, tantost quattre ou cinque enfans, tantost des Juifs, tantost de vielliards tout nuds, d'un bout de rue à autre." See Michel de Montaigne, Journal du Voyage de Michel de Montaigne en Italie, par la Suisse et l'Allemagne, en $1580 \& 1581$, vol. 2 (Paris, 1774), 140.

${ }^{34}$ This source, entitled Feste, baccanali et altro che era in uso del popolo Romano et altro che dai Pontefici sono stati alienati per il bon governo della città di Roma, may be found in BAV, Urb. Lat. 1714, f. 97r. On this matter, see Clementi, Il Carnevale romano, 48-49; Milano, Il ghetto di Roma, 314.

${ }^{35}$ Lynn M. Gunzberg, Strangers at Home. Jews in the Italian Literary Imagination (BerkeleyLos Angeles-Oxford, 1992), 92.
} 
pigs in exchange for a payment of 10 florins, to which "in the mid-fifteenth century Pope Paul II [... ] added, 'in memory of Judas,' thirty florins destined to pay for Masses." 36

The Carnival was also the occasion for pernicious giudiate that proliferated as early as the fifteenth century and became increasingly elaborate in the seventeenth and eighteenth centuries. In the Avvisi di Roma there is evidence of a giudiata performed in the Eternal City in 1609, only sixty-four years after the establishment of the ghetto. When a giudiata mocking a Jewish funeral was performed near the ghetto, the Jews "closed their doors and threw whatever they could find in their houses" at the masquerade's participants. After the police intervened, 140 Jews were arrested, while others managed to escape. ${ }^{37}$ A giudiata ridiculing the synagogue (schola delli Hebrei), staged on an ox-cart, was created and performed by a certain Francesco Palmieri during the 1666 Carnival. This man was arrested with other actors in the play, and a witness stated that he had given a large amount of money to some tradesmen (a carpenter, a decorator, and a painter) for the creation of the set design, which was stolen after Palmieri's arrest and never found. ${ }^{38}$ Carnivals, as Natalie Zemon Davis has shown, turned the world upside down by facilitating the construction of blurred boundaries and liminal spaces where symbolic violence could turn into real violence. Furthermore, according to Edward Muir, it "stimulated creativity, especially in theatrical productions and dance, social commentary, and even rebellion." ${ }^{39}$ It is precisely in this context that the early modern giudiate should be read and understood.

\footnotetext{
${ }^{36}$ Claudine Fabre-Vassas, The Singular Beast: Jews, Christians, and the Pig, trans. Carol Volk (New York, 1997), 162.

37 “....] I mascherati, che erano un buon numero passando per il ghetto degli Hebrei, questi dispiacendo l'irrisione di questa ceremonia, serrate le porte si misero a buttar sopra li mascherati quanta robba havevano in casa, et però furono molti di essi feriti et maltrattati, et però il Fisco ha havuto che investigare et di già si trovano più di 140 Hebrei prigioni, oltre li fugiti" (BAV, Urb. Lat. 1077, Avvisi di Roma, March 7, 1609). Concerning this event, see Boiteux, "Les Juifs dans le Carnaval de la Rome moderne," 758.

${ }^{38}$ The archival record of the trial was published by Emilio Re, "Qualche nota sul tipo dell'Ebreo nel teatro popolare italiano," Giornale storico della letteratura italiana 60 (1912): 383-98, and later in Anton Giulio Bragaglia, Le maschere romane (Rome, 1947), 228-29. On this case, see also Toschi, Le origini del teatro italiano, 337.

${ }^{39}$ See Natalie Zemon Davis, "The Reasons of Misrule: Youth-Groups and Charivaris in Sixteenth-Century France," Past and Present 1 (1971): 41-75. On episodes of violence and misrule during the Carnival and other urban festivals in early medieval France, see idem, "The Reasons of Misrule." For several Italian cases, see Guido Ruggiero, Binding Passions: Tales of Magic, Marriage, and Power at the End of the Renaissance (New York-Oxford, 1993), and Edward Muir, Mad Blood Stirring: Vendetta and Factions in Friuli during the Renaissance (Baltimore, 1993). On the wider social and cultural impact, see Edward Muir, Ritual in Early Modern Europe (Cambridge, 2005), 100.
} 
Despite the Jewish community's repeated protests to the Cardinal Vicar and the Sant'Uffizio, and notwithstanding the regular publication of edicts at Carnival time prohibiting the harassment of Jews in the city (Bando che non si debbano molestare, nè dar fastidio alli Hebrei) ${ }^{40}$ the performance of Jewish funerals became very popular. This was largely the result of efforts of the Roman fishmongers (pescivendoli) who ran their businesses in the rione Sant' Angelo that was close to the Jewish ghetto. They were "particularly active in organizing rituals of violence toward Jews, especially during the Carnival, and threatened them continually with 'robbing' their children to carry them away from the ghetto to the House of the Catechumens in the rione Monti. ${ }^{21}$ In February 1709, a century after the performance of the first known giudiata, and despite the ban issued by the governor of Rome on the presentation of Jewish-themed plays during the Carnival, the Company of Fishmongers staged a play, La Cassaccia (or Cassa degli ebrei). A couple of days after the first performance, although the play had been forbidden by the Cardinal Vicar and the Sant'Uffizio, Polish prince Alessandro Sobieski, who was in Rome for a visit, was permitted to attend an encore performance, provided that it was performed in a private setting-in the garden of the Palazzo Zuccari at Trinità dei Monti. But according to the testimony of a contemporary chronicler, because the gates remained open many Roman citizens entered and observed the play. ${ }^{42}$ Two years later, the Jews sent a memorandum to Pope Clement XI complaining about a play in which Christians would drag a coffin filled with severed animal heads through the streets of Rome, pretending to bury rabbis. ${ }^{43}$ In 1711 , another giudiata featured Jews riding donkeys, guided by a man disguised as the famous Rabbi Tranquillo Vita

\footnotetext{
${ }^{40}$ From 1595 onwards, these orders were published almost every year. On this matter, see Milano, Il ghetto di Roma, 322-23.

${ }^{41}$ Marina Caffiero, Forced Baptisms: Histories of Jews, Christians, and Converts in Papal Rome, trans. Lydia G. Cochrane (Berkeley-Los Angeles, 2012), 15. On the fishmongers' antiJewish activities, see idem, Legami pericolosi. Ebrei e cristiani tra eresia, libri proibiti e stregoneria (Turin, 2012), $362 \mathrm{ff}$.

${ }^{42}$ Francesco Valesio, Diario di Roma, 1708-1728, ed. Gaetano Scano, IV, February 9, 1709 (Milan, 1978), 381: "Tra gli molti carri che si sono preparati in diversi rioni per recitarsi in questo carnevale, gli pescivendoli ne havevano fatto uno intitolato La Cassaccia, nel quale rappresentavano ridicolosamente tutte le funzioni che sogliono fare gl'ebrei nel sepelire gli loro morti, per il che, havendo gli medici ebrei fatto ricorso non solo al cardinale vicario, ma anco alla congregazione del S. Officio, era stato proibito a' medesimi il farlo sotto gravi pene; ma, havendo il prencipe Alessandro, figliolo di questa regina di Polonia, desiderio di vederlo, ottenne di poterlo questa sera far rappresentare nel giardino del palazzino habitato da S. Maestà alla Trinità de' Monti, dove fu grandissimo il concorso di persone che v'andarono per vederlo."

${ }^{43}$ An excerpt from this memorandum may be found in Marina Caffiero, Legami pericolosi, 364.
} 
Corcos. ${ }^{44}$ In the same year, a play depicted Christians pretending to flay a Jew, cruelly wounding him as if he were a pig. ${ }^{45}$ In the ensuing years, various plays mocked unleavened bread (matzah) and other Jewish rituals while depicting Moses as half-human and half-pig. ${ }^{46}$

\section{Mocking the Jews of Rome (1647-1648?)}

In a brief annotation preceding the text of Palontrotti's giudiata, Pastrizio wrote that Palontrotti had taught the giudiata "to some bright boys who took part in the masquerade" and that this "was believed to be the first giudiata ever performed in Rome in 1647 or 1648, or perhaps just before or shortly after" those years. ${ }^{47}$ This last information is disputed by the testimony of humanist Maffeo Vegio da Lodi (1407-58), that the first giudiate had already made their appearance in the fifteenth century, ${ }^{48}$ preceding evidence of a masquerade mocking the Jews in the vicinity of the ghetto in 1609. Palontrotti's composition was not the first giudiata ever performed in Rome, but it may be that its text is the first to have come down to us in its original form. After introducing Palontrotti, Pastrizio gives some details about the occasion on which the text was composed and performed. It appears that the farce was performed upon the death of the "main rabbi or Morenu at that time, who was revered in the whole ghetto" of Rome. In Pastrizio's own words, "when he [the rabbi] died, Palontrotti arranged a giudiata in which Jews were intending to bury Rabbi Manoach, carrying his body in a box, but a pig was placed there in his stead." 49 Although the Hebrew adjective manoah is frequently used to designate a deceased person, it can also be translated into Italian as tranquillo ("calm"). This second interpretation suggests that the rabbi mentioned here is none other than Hizkiah Manoah (Tranquillo) Corcos, an ancestor of the more famous Hizkiah Manoah Hayyim (Tranquillo Vita) Corcos (16601730) the Younger, one of the most eminent and erudite Roman rabbis of the pre-modern era. ${ }^{50}$

\footnotetext{
${ }^{44}$ See Milano, Il ghetto di Roma, 326.

${ }^{45}$ See Caffiero, Legami pericolosi, 364.

${ }^{46}$ See Boiteux, "Les Juifs dans le Carnaval de la Rome moderne," 758.

${ }^{47}$ BAV, Borg. Lat. 481 , f. $172 r$.

${ }^{48}$ An excerpt from the manuscript codex preserved in the Ambrosiana Library is quoted in Bragaglia, Le maschere romane, 217.

${ }^{49}$ BAV, Borg. Lat. 481, f. $172 r$.

${ }^{50}$ On Tranquillo Vita Corcos the Younger, see Milano, Il ghetto di Roma, 247, 294, 311, 326, 391-93, 444; Giuseppe Sermoneta, "La cultura ebraica a Roma nel '700 alla luce di nuovi documenti," in Italia Judaica. Gli ebrei in Italia dalla segregazione alla prima emancipazione. Atti del III Convegno internazionale, Tel Aviv, 15-20 giugno 1986 (Rome, 1989),
} 
Rabbi Manoah was appointed chief rabbi of Rome in 1620 and remained at the helm for almost thirty years until his death. ${ }^{51}$ Although it seems that he held this position along with three other rabbis, he was considered "the dominant spirit" and his prominence as a Talmudist is well attested in several responsa. ${ }^{52}$ A careful reading of Palontrotti's giudiata reveals important details that confirm that the deceased Rabbi Manoah was Tranquillo Corcos the Elder. In two different passages, the song recalls the deceased rabbi's expertise in legal matters as well as his apparent role as a judge (dayyan): at first, it is said that he was knowledgeable about Jewish law ("era maskil nelli dinim"), then that he was able to resolve difficult quarrels ("A tutti li cosi kascim egli arrivava/A decider li liti tra i Madonim"). Moreover, Palontrotti says that he had a profound knowledge of the Mishnah (the Oral Law) "and the Rabbot," referring to the collections of Midrash Rabbah. The text adds an unclear reference to "the evil Rabbi Joschàk"-possibly a corrupt form of Hizkiah or Isaac - someone who was an expert in the Mishnah and clever, but who "was vulgar like Balak," the king of Moab whose failed efforts to curse the Israelites with the help of the prophet Balaam are recalled in Numbers $22-24$.

In addition to these features, the deceased rabbi was also proficient "in Leviathan and Behemoth"- the two monstrous creatures mentioned in Job (chapter 40) that are associated in rabbinic writings with the advent of the Messiah. This obscure allusion may have been intended to highlight the rabbi's familiarity with aggadic literature, to which reference is made disparagingly in another passage of the text, according to which the mouth of Rabbi Manoah "spat Midrasciòth" (used instead of Midrashim to rhyme with) and "pestered everyone with many Hagadoth."

According to the text of the giudiata, the rabbi "often studied grammar (dikduk)," and in another portion of the text, he is defined as an "advocate of poor defendants and the people" ("Sanigór delli nganim, e dello ngàm"). While no published works by Hizkiah Manoạ Corcos the Elder are extant,

69-96; Asher Salah, La République des Lettres. Rabbins, médecins et écrivains juifs en Italie au XVIIIe siècle (Leiden-Boston, 2007), 208-11; Caffiero, Forced Baptisms, passim; idem, Legami pericolosi, 40 ff.; idem, Il grande mediatore. Tranquillo Vita Corcos, un rabbino nella Roma dei papi (Rome, 2019). On his fight against the purchase and sale of non-kosher meat by Christian butchers in early eighteenth-century Rome, see Kenneth R. Stow, "The Jewish Dog and Shehitah," Interfaces 5 (2018): 175-93.

${ }^{51}$ Abraham Berliner, Geschichte der Juden in Rom vor der ältesten Zeit bis zur Gegenwart, II (Frankfurt-am-Main, 1893), 69 ff.; Hermann Vogelstein and Paul Rieger, Geschichte der Juden in Rom, II (Berlin, 1896), 198; Moritz Steinschneider, Die italienische Literatur der Juden vom 16. bis Ende 18. Jahre (Frankfurt-am-Main, 1901), 564. See also Louis Ginzberg, "Hezekiah Manoah Corcos," The Jewish Encyclopedia 4 (New York-London, 1903), 262-63.

${ }^{52}$ Ginzberg, "Hezekiah Manoah Corcos," 262-63. 
this last comment cannot be discounted, since he is known to have defended Italian Jews on several occasions. In 1620, for example, on behalf of the Roman community he petitioned Pope Paul V "to issue an order that Jews who had been imprisoned for debt by Christians should be cared for at the expense of the latter." ${ }^{53}$ Likewise, in 1624 he intervened in a case of confiscation of Hebrew books in Modena, addressing a letter to his friend Pellegrino Sanguinetti to inform him of the law in force (the papal bull of Clement VIII from 1593 and the decree of the Sacred Congregation of the Index dated August 24,1596$)$ regarding the ownership and expurgation of Hebrew books. ${ }^{54}$

Although Pastrizio dated the composition to around 1647 or 1648, it is apparent that by his own admission he did not remember the exact date. The archival documentation indicates that Hizkiah Manoah Corcos died shortly before 1650 , or at the very latest in the first half of that year, since a document dated August 1650 hints that the Jewish community was mourning his passing. ${ }^{55}$ How the text of the song came into Pastrizio's hands is not known. But had he been relying on his own memories to date the composition, he may well have been confused, since he was only twelve years old when he arrived in Rome from Dalmatia to join the Collegio dei Neofiti e Transmarini in $1648 .^{56}$

The metrical composition-mostly ottave di ottonari with an ABABCDCD and ABABABCC rhyme scheme, usually obtained by placing Hebrew words at the end of each verse-reveals the influence of Italian poetic forms such as terza rima, quartina, and ottava rima, which were often sung or "associated with a declamatory style of performance." 57 Pastrizio also stated that the composition was a song (canzone), and provided indications of the alternation of the main anonymous soloist and the chorus, as well as brief solo sections. There must have been seven or eight characters involved in the giudiata, plus the dead Rabbi Manoah, who is represented by a pig. In one stanza of the song, at least seven people (Rabbi Ahavah, Istzchàk, Gabriello, Mardochài, Tarfòn, fu Dolcetta, and Raffaello) are addressed by another Jewish individual who seems to have been the protagonist and narrator of the event (perhaps performed by Palontrotti himself). Unfortunately,

\footnotetext{
${ }^{53}$ Schulim Ochser, "Rome," The Jewish Encyclopedia, vol. 10 (New York-London, 1905), 456.

${ }^{54}$ Corcos's handwritten letter was published in Moritz Stern, Urkundliche Beiträge über die Stellung der Päpste zu den Juden mit Benutzung des päpstlichen Geheimarchivs zu Rom (Kiel, 1893), 181 n. 163.

${ }^{55}$ See Berliner, Geschichte der Juden in Rom, II, 54-55.

${ }^{56}$ See Mrkonjić, "Pastrizio, Giovanni."

${ }^{57}$ Avery Gosfield, "I Sing It to an Italian Tune... Thoughts on Performing Sixteenth-Century Italian-Jewish Poetry Today,” European Journal of Jewish Studies 8/1 (2014): 11.
} 
we have no indication as to whether there was a fixed musical score or if it was accompanied by instruments.

There is no doubt that the metrical composition reveals Palontrotti's deep knowledge of both Hebrew and Judeo-Roman. ${ }^{58}$ Some characteristic elements of this dialect stand out, as in the case of the Hebrew letter shin, which is rendered as $s c$ (instead of $s h$ ), or of the letter ayin, which is transliterated as $n g$ (instead of '):

Nella bocca era il Devàsc,

Nello core lauda lo Ròsc,

Che lo rendeva come Ngàsc,

E diceva ch'era Parngosc.

While the use of the verb haio to indicate the past tense of "to have" and the expression negro $\mathrm{mi}^{59}$ to signify "oh, poor me," denote archaic forms of the Roman dialect (or romanesco), other verbs are entirely Judeo-Roman. Both the verbs accolare (from the Hebrew le-ekhol) meaning "to eat" and ngalnare meaning "to look at" (from the Hebrew "ayin, "eye") have clear Hebrew origins. ${ }^{60}$

The plot of Palontrotti's giudiata is quite simple and recalls some of the most prevalent anti-Jewish stereotypes of early modern Italy. As Pastrizio noted, the entire composition claims to praise the deceased rabbi but by the end mocks him. Each ottava is articulated in a pars construens followed by a pars destruens. Whereas the first verses of the stanza highlight the rabbi's good qualities, the second verses aim to tarnish his image. The song opens with an exhortation to mourn for the loss of the rabbi who "used to carry the tephillim"-small leather boxes containing scrolls of parchments inscribed with scriptural quotations and worn during morning weekday prayers- - "but

\footnotetext{
${ }^{58}$ For a bibliography of giudaico-romanesco, see Attilio Milano, "Vocaboli ed espressioni di origine ebraica nel dialetto giudaico romanesco," in Crescenzo Del Monte, Sonetti postumi giudaico-romaneschi e romaneschi (Rome, 1955), 236-60; Lea Scazzocchio Sestieri, "Sulla parlata Giudaico-Romanesca," in Scritti in memoria di Enzo Sereni (Milan-Jerusalem, 1970), 101-32; Sandra Debenedetti, "Il giudeo-romanesco," MA thesis (Università degli Studi di Roma, 1969-1970); idem, "Parole in giudaico-romanesco in una commedia del Bernini," Lingua nostra 31 (1970): 87-89; Elio Toaff, "Il giudaico-romanesco: una testimonianza," in Il romanesco ieri e oggi. Atti del convegno del Centro Romanesco Trilussa e del Dipartimento di Scienze del Linguaggio dell'Università di Roma "La Sapienza," ed. Tullio De Mauro (Rome, 1989), 249-55; Jana L. De Benedetti, "Dabbera in Scionaccodesce (Speak GiudaicoRomanesco): Keeping the Jewish-Roman Dialect Alive," PhD diss. (State University of New York, Albany, 1997).

${ }^{59}$ See Milano, Il ghetto di Roma, 461; Scazzocchio Sestieri, "Sulla parlata GiudaicoRomanesca," 121.

${ }^{60}$ Another known form of accolare was achlàre; cf. Milano, Il ghetto di Roma, 448. See ibid., 461 (ngkàinare) for ngalnare.
} 
who believed like Laban," the Aramean who tricked Jacob into marrying his elder daughter Leah when he believed he was marrying her younger sister Rachel (Genesis 29:14-30). The meaning of the phrase "he believed like Laban," as a marginal note to the text explains, is "to be idolatrous," which accords with the biblical account in Genesis 31:19, 32. The deceased rabbi is then described as a teacher (moreno, the Roman form of the Hebrew morenu), a renowned judge (dayyan), an expert in legal matters ("maskil nelli dinim," "a decider li liti tra li Madonìm"), and a rabbi (rabbeno, rhyming with moreno) "who was associated with scedim [demons]." This pernicious affiliation is also recalled in the ensuing stanza: "May he be blessed, alive or dead, unlike the goyim who, even though they are wrong, speak the truth about the rabbi who was taken away by demons." Further on, it is said that "the black angels snatched and dragged him, consigning his soul to Lilith," who, as stated in the corresponding note, "was a witch and the mother of demons." 61 Following this, Rabbi Manoah is termed a "fortune-teller of past deeds" who "must be cursed like Ham's son" Canaan, who "saw his father's [Noah's] nakedness." ${ }^{62}$ These associations serve the author's goal of presenting false praise of the Roman rabbi. They may also offer an idea of what spectators who stopped to watch the giudiate in the city streets may have been able to understand.

Other evocative images are employed to describe the rabbi's animal nature and physical appearance. While his hands were "beautiful and delicate," "his neck, eyes, and nose were red and made people laugh" and "his head was full of lice [kinnim]"; his mouth is depicted as "full of honey" and "sugared," though "he praised bitterness in his heart." This last, curious feature "made him look like a moth ("ash, lit. ngasc) although he considered himself as a flea (par'osh, lit. parngosc)." While these allusions are admittedly quite obscure, we might hazard a guess at their meaning. The first similarity may refer to the winged insect's destructiveness, as acknowledged amply in Job, Isaiah, and Hosea, as well as in the Gospels. ${ }^{63}$ The image of the flea is likely to have been used to describe the rabbi's supposed humility. In other passages, Palontrotti adds information about the rabbi's disposition, saying that he was "sharper than camels [gamalim]," "fearless," and "hard-hearted and stiff-necked [kascè lev, kascè ngòreph]." In the end, these comparisons, which are meant to describe the rabbi and mock his characteristics, were no more than a prelude to his ultimate transformation into an animal. After the narrator's invitation to mourn "for the cruel [achazarà] death of the rabbi,"

\footnotetext{
${ }^{61}$ The only reference to Lilith as a wilderness demoness in the Bible is Isaiah 34:14.

${ }^{62}$ Genesis 9:23.

${ }^{63}$ See the entry for "Moth" in The Popular and Critical Biblical Encyclopaedia and Scriptural Dictionary, ed. Samuel Fallows (Chicago, 1911) II, 1191.
} 
he urges the other participants to "calmly sing the burial hymn [Menuchà]," adding a quotation from Isaiah $28: 10$, "for it is precept by precept, precept by precept, line by line, line by line." The ritual hints at Roman familiarity with Jewish funeral processions, which began in the ghetto and ended in the Jewish cemetery on the Aventine. ${ }^{64}$

Roman acquaintance with Jewish religious traditions is evident throughout the giudiata. In four distinct passages, the narrator addresses blessings to the rabbi or to some specific parts of his body, starting his sentences with baruch and its Italian translation benedetto (blessed). The deceased rabbi may be blessed (baruch) "whether alive or dead" and benedetto "like Ham's son"; in other words, "cursed." 65 Other "blessings" refer to his head "full of lice" and to his mouth, hands, neck, eyes, and nose. The result is the damnatio memoriae of Rabbi Manoah, whose memory, instead of being praised with the usual honorifics for the deceased, "may his memory be a blessing" (in Hebrew, zikhronò li-vrakhà) or "peace be upon him" ("alav ha-shalom), is damned with the formulas "may his memory be cursed (zikhronò li-qlalà) and "may his name and memory be blotted out" (yimah shemò we-zikhronò).

And now, the final scene. When the funeral participants notice movement inside the coffin, they think that a miracle has taken place, exclaiming mazal tov. But when they come closer and see the rabbi's swollen body, they realize that something very dreadful (mazal ra) has occurred: the rabbi has become a pig, or, more precisely, his soul (nefesh) has entered a pig, the non-kosher animal par excellence. ${ }^{66}$ This sort of disembodied spirit—a dybbuk $k^{67}$-raises initial perplexity among those in attendance. One declares that this event has no precedent in the sacred texts of Judaism-Torah, Talmud, or Midrash. Another says (or perhaps asks someone else whether it is true) that the Talmud, tractate Avodah Zarah, states that the Jews will eat pork in the world to

\footnotetext{
${ }^{64}$ This only became the Jewish burial place in the sixteenth century, and it was used until 1934. Before this time, in the Middle Ages, the Jewish cemetery (also known as the ortaccio degli ebrei or the Campus Iudeorum) was located just outside the Porta Portese, near Trastevere. See Berliner, Geschichte der Juden in Rom von der ältesten Zeit bis zur Gegenwart, passim; Daniela Di Castro, I tesori del Museo ebraico di Roma: Guida alla visita e alle collezioni (Rome, 2010), 47.

${ }^{65}$ See Genesis 9:23.

${ }^{66}$ On this animal and the interpretations of it in Judeo-Christian traditions, see Isaiah Shachar, The Judensau: A Medieval Anti-Jewish Motif and Its History (London, 1974); Fabre-Vassas, The Singular Beast: Jews, Christians, and the Pig.

${ }^{67}$ In Jewish lore, the Yiddish word dybbuk (from the Hebrew davak, meaning "to adhere") refers to an evil spirit or the soul of a dead person that inhabits the body of another living human being. Although the term seemed to have been well known by the sixteenth century, it became popular only after S. Ansky's play The Dybbuk, or Between Two Worlds (191316). For this phenomenon in the early modern era, see at least J. H. Chajes, Between Worlds. Dybbuks, Exorcists, and Early Modern Judaism (Philadelphia, 2003).
} 
come ('olam haba). Rabbi Manoah, "our teacher (moreno)"- -he goes ondecided to "appear in the form of a pig (hazir) to reassure both young people and adults" that this is so. The song concludes with an invitation to rejoice at this extraordinary event, to sound the shofar in the Roman ghetto, confirming that one may eat pork "without any respect" and with no concern for Jewish legal constraints.

\section{Conclusion}

It appears that the manner in which early modern Italian Jews spoke was perceived as alien to the surrounding environment. By reproducing their languages, combined with regional Italian dialects, Christian authors aimed to produce comic effects in sixteenth-century plays. During the Baroque period, thanks especially to the great popularity of the commedia dell'arte, "the dialects of Italian Jews furnished still another pretext to portray Jewish characters and, indeed, people whose speech seemed garbled, who yelled or babbled incomprehensibly were often the elements of farce." 68 The first traces of this trend can be found in Orazio Vecchi's Amfiparnaso (Venice, 1597) and a little earlier in Zan Fritada's Ragionamento tra due Hebrei (published in Pesaro in 1588, but probably already known by 1585). In each of these plays, a dialogue between two or more characters "constitutes the dramatic soul of the scene." 69 It was indeed through a dialogue between a character named Francatrippa and the Jews of Modena that Vecchi conveyed his comic (re)presentation of the Hebrew language and Jews in his "comedia harmonica." This scene takes place in the pawnshop inside the ghetto, and the language spoken by the Jews sounds more or less as follows: "Ahi Baruchai/Badanai Merdochai/An Biluchan/Ghet Milotran/La Baruchabà."70

\footnotetext{
${ }^{68}$ Gunzberg, Strangers at Home, 94. On the commedia dell'arte, with glimpses of Jewish performances in early modern Italy, see Erith Jaffe-Berg, The Multilingual Art of Commedia dell'Arte (Ottawa, 2009) and, more recently, Commedia dell'Arte and the Mediterranean. Charting Journeys and Mapping "Others” (Farnham, 2015).

${ }^{69}$ Erica Baricci, "La scena 'all'ebraica' nel teatro del Rinascimento," Acme. Annali della facoltà di Lettere e Filosofia dell'Università degli Studi di Milano 53/1 (2010): 135-63, 143. The translation is mine.

${ }^{70}$ L'Amfiparnaso. Comedia harmonica d'Horatio Vecchi da Modona (Venice, 1597), act III, scene 3. As suggested by Don Harrán, while "baruchabà is based on Ps. 118:6, baruchai is possibly a conflation of barukh and Adonai, and ghet is not only derived from the Italian ghetto but perhaps from the Hebrew get (divorce) or het (sin), several others, such as merdochai, are not Hebrew at all. See Don Harrán, "Barucaba as an Emblem for Jewishness in Early Italian Art Music," The Jewish Quarterly Review 98/3 (2008): 328-54; and idem, "Between Exclusion and Inclusion: Jews as Portrayed in Italian Music from the Late Fifteenth to the Early Seventeenth Centuries," in Acculturation and Its Discontents. The Italian Jewish Experience
} 
A little later in the farce, the text emphasizes words such as Baruchabà and gòi as well as moscògn ("pawn") and perachèm ("florins," or more generally "money") that were doubtless familiar to Christians since they regularly borrowed money from Jewish moneylenders. ${ }^{71}$ Other Christian playwrights pursued ironic aims by inserting Jewish characters into their comedies. Such works include La tempesta amorosa (Venice, 1605) by Alessandro Donzellini; Lo schiavetto (Venice, 1610) by Giovanni Battista Andreini; $L i$ strapazzati (Rome, 1627) by Giovanni Briccio; the Fontana di Trevi (Rome, 1644) by Gian Lorenzo Bernini; and L'ebreo finto conte, overo Tognino impazzito (Todi, 1697). ${ }^{72}$

Another popular topos of Renaissance and Baroque Italian theater was the representation of a scaramuccia or baruffa-a quarrel-between "two or more outlandishly dressed and masked characters becoming increasingly upset with each other." 73 Although the origins of this theme are almost certainly to be found in Teofilo Folengo's Baldus (first published in 1517), it did not gain popularity until the seventeenth century as a quarrel over the smuggling and killing of a goose. This is the case as well for Le veglie di Siena (Venice, 1604) by the aforementioned Orazio Vecchi and also for Giulio Cesare Croce's Rissa tremenda fra Mardochai e Badanai in his La scatola historiata (Bologna, 1605) and his Scaramuccia grandissima occorsa nuovamente nella città d'Ancona fra due ebrei per un'ocha (Modena, 1609).

Traces of comic quarrels about circumcision (lazzi della circoncisione) are found in works such as the Novantanove disgrazie di Pulcinella and the Ragionamento tra due Hebrei, analyzed by Erica Baricci. ${ }^{74}$ In due course, anti-Jewish stereotypes assumed a less ironic inflection and offered entree to the degraded conditions in Jewish ghettos. This is the case, for example, in the well-known 'Gnora Luna (1752), which consists of four

between Exclusion and Inclusion, ed. David N. Myers, Massimo Ciavolella, Peter H. Reill, and Geoffrey Symcox (Toronto, 2008): 72-98.

${ }^{71}$ See Fortis, La parlata degli ebrei di Venezia, 20. On the use of an imitation of the Hebrew way of speaking in the Amfiparnaso, see also Maria L. Mayer Modena, "Il giudeo-italiano: riflessioni sulle fonti," in Atti del XVI Convegno internazionale dell'AISG, Gabicce Mare, 1-3 ottobre 2002, ed. Mauro Perani, Materia Giudaica 8/1 (2003): 65-73.

${ }^{72}$ For a reflection on the "Jewish-style scenes" (scene all'ebraica) in these and other plays, see Maria L. Mayer Modena, "A proposito di una scena 'all'ebraica' nello Schiavetto dell'Andreini," Acme. Annali della facoltà di Lettere e Filosofia dell'Università degli Studi di Milano (Milan, 1990): 73-81; Barbara Santambrogio, "Il giudeo-italiano nelle fonti esterne: Li Strapazzati di Giovanni Briccio," Acme. Annali della facoltà di Lettere e Filosofia dell'Università degli Studi di Milano 50/1 (1997): 245-58; Baricci, "La scena 'all'ebraica' nel teatro del Rinascimento."

${ }^{73}$ Gunzberg, Strangers at Home, 94.

${ }^{74}$ See Baricci, "La scena 'all'ebraica' nel teatro del Rinascimento," 149-53. 
canzonette "grotesquely satirizing Jewish marriage customs, greed, dishonesty, and love of money."75 While the employment of Jewish themes and the imitation of the Italian Jews' manner of speaking were intended for comic effect, Palontrotti exploited them as support for his narrative and specifically for its polemical purpose. The final exhortation to eat pork, though undoubtedly flippant, may reveal a not-so-subtle prompt to conversion.

The demonization and dehumanization of the Jew, first through his association with devils and demons, then through his identification with pigs, had epitomized the Christian popular imaginary since the Middle Ages. ${ }^{76}$ The association with pigs found multifarious expressions in different times and places, from the medieval Judensau ${ }^{77}$-a representation of Jews feeding from the teats of a sow-and blood libels to the early modern giudiate performed in the Roman ghetto, from the circulation of antisemitic treatises and canards, including Nazi and Fascist propaganda, to the many vulgar episodes that have occurred in more recent times. ${ }^{78}$ These and other anti-Jewish leitmotifs, such as ridiculing matzah or the profanation of the Tetragrammaton that recur in other eighteenth-century giudiate, were not intended merely to poke fun at the Jews and their customs, traditions, and language. They must also be understood as at the roots of modern antisemitism.

\footnotetext{
${ }^{75}$ Gunzberg, Strangers at Home, 95 . The original play Gnora Luna or Lo Sposalizio di Baruccabà colla Signora Luna e morte di essa was composed in Florence in 1752, but it was reprinted many times up until the twentieth century. This series of canzonette also included Luna's death, Baruccabà's second marriage to Diana Stimisciò, and finally, Baruccabà's death after being thrown into the river. On this play and the reconstruction of its origins, see Ezio Levi, "La Signora Luna," Giornale storico della letteratura italiana 67/1 (1916): 98-114; Benè Kedem, "La Gnora Luna. Scene di vita ebraica fiorentina," La Rassegna Mensile di Israel 6/11-12 (1932): 546-79.

${ }^{76}$ See Joshua Trachtenberg, The Devil and the Jews: The Medieval Conception of the Jews and Its Relation to Modern Antisemitism (New York, 1961); Shachar, The Judensau: A Medieval Anti-Jewish Motif and Its History; Fabre-Vassas, The Singular Beast: Jews, Christians, and the Pig.

${ }^{77}$ This image originated in thirteenth-century Germany and circulated mostly in Germanspeaking areas. The Judensau was represented on the walls of several German churches, including Wittenberg Cathedral, as well as on woodcuts, broadsheets, and playing cards. At the end of the fifteenth century, it was also linked to the martyrdom of Simon of Trent; on this image, see the studies by Shachar and Fabre-Vassas (above. n. 66).

${ }^{78}$ Recent incidents that draw on these themes include the delivery of three pig's heads to the Roman Jewish community just before Holocaust Remembrance Day in 2014 (January 27) and the raising of banners by supporters of the A.S. Roma soccer team bearing slogans such as "Lazio fans don't eat pork" (Laziale non mangia maiale) followed by a swastika. Following this episode, the same slogan appeared on the city walls in 2017 and again in early 2018.
} 
Finally, the particularly harsh tones that characterize Palontrotti's giudiata need to be examined in light of Roman popular traditions during the Carnival. It is also possible that the text reflects the author's personal and violent dislike of the deceased rabbi, who, as I have proposed, should be identified with Tranquillo Corcos the Elder, who must have died some years before the publication of Palontrotti's Breve Risposta to Simone Luzzatto. If this assumption is correct, then this Roman polemicist can certainly be considered one of the most significant interlocutors of the chief rabbis of the two most important Jewish communities, Rome and Venice, during his lifetime. Further research on Melchiorre Palontrotti and his published writings (and perhaps also the discovery of other unknown works) will help to extend the limited knowledge of his role in seventeenthcentury anti-Jewish propaganda, his relationships with representatives of the church and the Jewish community of Rome and, more importantly, his educational background and deep understanding of Hebrew and JudeoRoman.

Acknowledgments Open Access funding provided by Projekt DEAL. The present contribution is a slightly revised version of a talk given at the 64th Annual Meeting of the Renaissance Society of America, held in New Orleans, Louisiana, in March 2018. I wish to thank EMoDiR (Early Modern Religious Dissents and Radicalism), and particularly Federico Barbierato, Stefano Villani, and Xenia von Tippelskirch, for organizing the "Early Modern Jewish-Christian Polemics in Context" panel, and Bernard D. Cooperman, Adam Shear, Benjamin Ravid, Emily Michelson, and Flora Cassen, among others, for their inspiring insights and suggestions. I also owe my gratitude to Anthony Grafton and Joanna Weinberg for allowing me to give a brief presentation about the giudiata at the Fall Weekend Seminar entitled "The Many Faces of Hebraism in Early Modern Europe" held at the Folger Institute, Washington DC (September 13-14, 2018). Finally, I thank the anonymous reviewers, the journal editors, and Daniel Davies and Michaël Gasperoni for their valuable comments and good advice.

Publisher's Note Springer Nature remains neutral with regard to jurisdictional claims in published maps and institutional affiliations.

Open Access This article is licensed under a Creative Commons Attribution 4.0 International License, which permits use, sharing, adaptation, distribution and reproduction in any medium or format, as long as you give appropriate credit to the original author(s) and the source, provide a link to the Creative Commons licence, and indicate if changes were made. The images or other third party material in this article are included in the article's Creative Commons licence, unless indicated otherwise in a credit line to the material. If material is not included in the article's Creative Commons licence and your intended use is not permitted by statutory regulation or exceeds the permitted use, you will need to obtain permission directly from the copyright holder. To view a copy of this licence, visit http://creativecommons.org/licenses/by/4.0/. 


\section{Appendix}

Bibliography of Palontrotti's Published Writings

1640 Lettione sopra il Salmo 8, di Melchior Palontrotti. Della grandezza del nome di Giesu, in Roma, nella Stamperia della Reu. Camera Apostolica

All'em.mo e Rev.mo Sig. Card. de Torres. Lettione sopra il Salmo 36, di Melchior Palontrotti fatta nell'Accademia di Monsig. Alessandro Sperelli, in Roma, nella Stamperia della Reu. Camera Apostolica Lettione sopra il Salmo 44, secondo il testo hebreo 45, di Melchior Palontrotti. Della bellezza di Christo, in Roma, nella Stamperia della Reu. Camera Apostolica

1641 Lettione V. sopra il Salmo 49, di Melchior Palontrotti. Della S.ma Trinità e vocatione delle genti. Deus Deorum Dominus locatus est et uocabit terram a solis ortu usque ad occasum, in Roma, appresso Francesco Moneta

Lettione VI. di Melchior Palontrotti, sopra il Salmo LXXI. Dell'Amor Divino. Titulus Psalmi Salomonis, in Roma, Appresso Manelfo Manelfi; Lettione VII. Della Passione di Christo, Psalm 21. Lamnatseach ngal aieleth hasciacar. Victori super cerua aurorae (di seguito al precedente, 9-12), in Roma, appresso Manelfo Manelfi

Breve risposta a Simone Luzzatto ebreo, in Roma, appresso Manelfo Manelfi

1642 Lettione VIII sopra il Salmo 84. Del Trionfo d'Amore, in Roma, appresso Manelfo Manelfi

Sferza contro l'ostinazione, et pervicacia de gl'ignoranti Ebrei, di Melchior Palontrotti. Ad istanza di Pietro Paolo Romaldi, in Bracciano, per Andrea Fei, Stampatore Ducale

1647 Disputa del Christiano con l'Ebreo di Melchior Palontrotti. Ad istanza di Pietro Paolo Romaldi. Dove si prova chiaramente contra l'ebreo, che la ridutione temporale, che aspetta fù adempita nella liberatione di Babilonia, in Roma, appresso Girolamo Barbèri

1649 Breve raccolta d'argomenti cavati dalla Sac. Scrit. \& dall'Antiche tradittioni di Rabbini, con le quali chiaramente si provano $i$ dogmi della Religion Christiana contra l'Hebraica perfidia. Opus utilissimum Iudaeis ad eorum obstinationem, et incredulitatem agnoscendam, in Venetia, appresso Giovanni Giacomo Herz 
BAV, Borg. Lat. 481, "Canzone contro gli ebrei. Precedono notizie su Melchiorre Pallantrotti di mano di Giovanni Pastrizio," ff. 172r-174r ${ }^{79}$

Melchior Pallontrotti Romano era peritissimo nella lingua Ebrea, e fiero contra gli ebrei. Stampò contro di loro delle loro sciocchezze, andava alle sinagoghe, li sburlacchiava, et alle prediche loro si trovava spesso, e le interrompeva notando gli spropositi al Rabbino. Era à suo tempo il principale Rabbino ò Morenu stimato somamente da tutto il Ghetto Rabbi Manóach e quando morì, il Pallontrotti fece una mascherata d'Ebrei ch'andavano à sepelir Rabbi Manóach portandolo in una cassa, mà in sua vece ci haveva messo un porco vivo, con artificio che quando si voleva s'apriva la cassa per un poco al porchetto detto חזיר Chazir da gli ebrei cavava fuori il capo. Il canto che compose Pallontrotti lo fece imparare à lesti giovini che componevano la mascherata. E si crede la prima Giudiata in Roma. Non so ch'anno fusse se 1647 ò 1648, ò poco prima ò poco dopo. Mostra la canzone di lodarlo mà lo beffa.

Piangete Talmidim, ${ }^{1}$

Ch'è morto lo Rabbàn, ${ }^{2}$

Che portava i Tephillim, ${ }^{3}$

Ma credeva come Labàn. ${ }^{4}$

Nella bocca era il Devàsc, ${ }^{5}$

Nello core lauda lo Ròsc, ${ }^{6}$

Che lo rendeva come $\mathrm{Ngàsc},{ }^{7}$

E diceva ch'era Parngosc. ${ }^{8}$

Quella bocca saporita,

Che sputava Midrascioth ${ }^{9}$

Che ti dava la marcia vita

Con li tanti Hagadoth. ${ }^{10}$

Chi l'arriva nella Miscnà? ${ }^{11}$

Quel Rasciany ${ }^{12}$ di Rabbi Joschàk,

Che non hà se non Nghormà, ${ }^{13}$

E si disdice come Balàk.

È morto lo Moreno ${ }^{14}$

Ch'era maskil ${ }^{15}$ nelli Dinim, ${ }^{16}$

Si poteva dir Rabbeno ${ }^{17}$

Confederato coi scedim. ${ }^{18}$

Barùch $^{19}$ vivo e morto

A dispetto delli Goim, ${ }^{20}$

Che il vero dicono à torto

L'hanno portato i Scedim. ${ }^{21}$

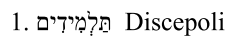

2. Rabban רכריז Maestro grande

3. תִִּלרין frontali o pendacoli

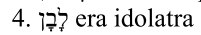

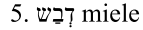

6. ראשבש fiele

7. שֶ tignola

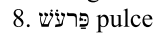

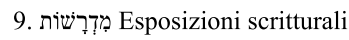

10. פֵַַּדות Sensi allegorici

11. מִשֶָׁדות Miscnà. Rito del Talmùd

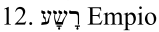

13. עוֹרְָּ Astutia

14. מוֹרֵנוֹ Dottore

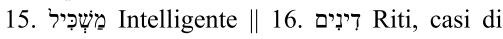
coscienza

17. רברֵּנוֹ Maestro, Rabbino

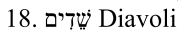

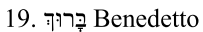

20. גוֹיוֹים Gentili, intendono i Cristiani

21. שֶׁדים גemonij

\footnotetext{
${ }^{79}$ The text offered here is a transcription of Pastrizio's handwritten giudiata. It is not known whether the notes containing the Hebrew words and their corresponding Italian meanings were in Palontrotti's original text or were added by Pastrizio. The italics, which are intended to highlight the Hebrew words in the main text, are mine.
} 


\section{Seguono a cantare pure d'accordo}

Tutto di chosciech $^{22}$ si vesta lo ngolàm $^{23}$ Per la morte achazară ${ }^{24}$ dello Rabbino

Sanigó $r^{25}$ delli nganìm, ${ }^{26}$ e dello ngàm, ${ }^{27}$

Delli cosi passati grand'Indovino.

Sia benedetto come il figlio di Cham.

Li scuri Malachim ${ }^{28}$ à un'ancino

Preso di posta l'hanno strascinato, et in poter di Lilith ${ }^{29} 1$ 'han consegnato.

Benedetto lo Ròsc,${ }^{30}$ dove posava

Un numero infinito di kinnìm ${ }^{31}$

Ch'il Dikduk $k^{32}$ spesso contemplava

Ch'era più Chad $^{33}$ che non i gamalim. ${ }^{34}$

A tutti li cosi kascim $^{35}$ egli arrivava.

A decider li liti tra i Madonim, ${ }^{36}$

Esperto nel Leviathàn ${ }^{37} \mathrm{e}$ Behemòth, ${ }^{38}$

Sprofondato Maschil ${ }^{39}$ nello Rabbòth. ${ }^{40}$

Barùch $^{41}$ sia quella bocca inzuccherata

Quelli mani Japhim ${ }^{42}$ e delicati

Lo $o z a v a ̀ r^{43}$ e la faccia mascherata

Li Nghenàim $^{44}$ e'l charùm $^{45}$ scarpellati

Ch'eran Causa di riso alla brigata

Kascè $^{46}$ lev $^{47}$ kascè $^{48}$ ngòreph ${ }^{49}$ in tutti i lati,

$\mathrm{Ne}$ pàchad ${ }^{50}$ hebbe mai sino alla morte

Seben del Ghehinàm ${ }^{51}$ vidde le porte.

Rabbi Ahavàh, Istzchàk e Gabriello,

Mardochài, Tarfòn, e fu Dolcetta,

Venite tutti voi con Rafaello,

Che lo Rabbi Manóach già v'aspetta.

Cantate la Menuch $\grave{a}^{52}$ senza bordello,

Rav la Rav (Kav la Kav), ${ }^{53}$ Tzav la tzàv, ${ }^{54} \mathrm{e}$ senza fretta.

Stati forti alli Leggi e alla Miscnà ${ }^{55}$

Che goderete lo ngolàm habbà. ${ }^{56}$

Ohi lechachàm mechukàm ve Rav Rabanàn ${ }^{57}$

In vita et in morte schiavo dello Satàn

Zichronò liklalàh. ${ }^{58}$ Amen.

Jimàch scemò vezichronò ${ }^{59}$ Amen.

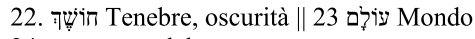

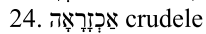

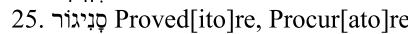

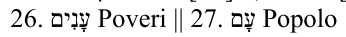

28. מָלָָאָדים Angeli

29. לִילִת Strega madre de' Diavoli

30. שา Capo

31. קינינים Pedocchi

32. דִ דִקוּוּרום Grammatica

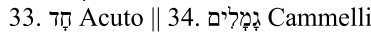

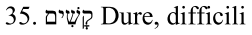

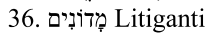

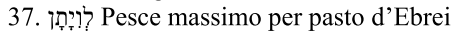

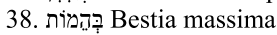

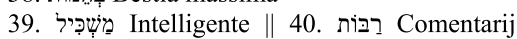
copiosi et antichi sopra la Legge ò Pentateuco

41. בָּר Benedta

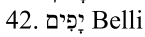

43. צִיפוּר Collo

44. חָרוּם 45 Naso schiacciato

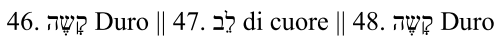

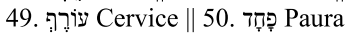

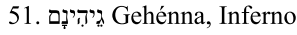

52. Rִ מָנוּכָה Requiem, ò riposo

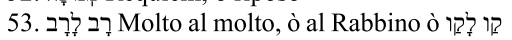

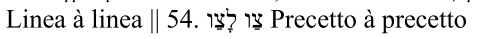

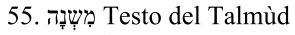

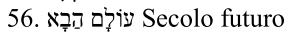

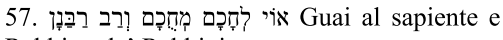
Rabbino de' Rabbini

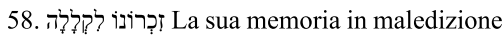

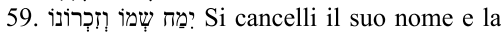
sua memoria

Tutti insieme quando si muove il morto, cioè cava fuori la sua testa il porco gridano 
Mazàl tov. ${ }^{60}$

Nghalnati $^{61}$ Rabbi Ahavà, par che si mova

Lo Morenu nella cassa. Vediam la prova.

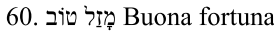

61. עִינָ Vedete, mirate

Un della compagnia dice

O negro mi: guarda che capo grosso

La chochma ${ }^{62}$ gli hà gonfio sino l'osso.

62. חדכְדמָה Sapienza

\section{Un'altro}

Mazal rangh $!^{63}$ Lo nephesc ${ }^{64}$ dello Rabbi dentro 63. נָפָּש . Mala sorte Anima no porco

\section{Un'altro}

Haio visto tutto il Talmud,

Studiato le Perascioth ${ }^{65}$

Squinternato le Ghemaròt ${ }^{66}$

Rivoltato li Rabbòth, ${ }^{67}$

Né trovo alcuno del Zérang ${ }^{68}$ sia entrato

Mai nello Chazìr, ${ }^{69}$ se non salato.

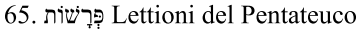
66. גְמֵרוֹת Commenti del Talmud autentici

67. רַבּוֹ Comentarij copiosi et antichi sul Pentateuco

68. זָרָע Seme

69. חזָזיר Porco

Dice l'altro

Hai letto mai nello Trattato Ngavodà zarà ${ }^{70}$

Che se accòla ${ }^{71}$ il Chazìr ${ }^{72}$ nèl Ngolàm habbà! $!^{72}$

Ecco il nostro Moreno

Che per assicurar huomini et putti

In forma di Chazir ${ }^{74}$ si mostra à tutti.
70. עָבוֹדָדה זָרָה

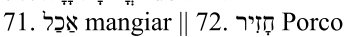

73. עוֹלְם הבָא Secolo venturo

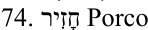

\section{Tutti insieme gridano}

Simchà $\grave{a}^{75}$ à Chachamìm, ${ }^{76}$

Sasciòn $^{77}$ à i Parnasim..$^{78}$

Fate Chagh $^{79}$ ò Jehudim,

Sonate lo sciophàr $r^{80}$ per tutto il ghetto

Accolate ${ }^{81}$ Chazir $^{82}$ senza rispetto.

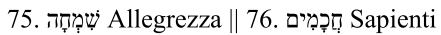

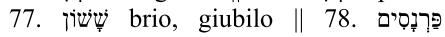
Governatori || 79. חָָ Festa, solennità 80. שוֹפר Tromba

81. חָכָל Mangiate || 82. מָזיר Porco

Fine. 